\section{Prof. N. I. Vavilov}

Prof. N. I. VAvilov, whose work is mentioned above, was a pupil of Bateson at the John Innes Horticultural Institution, London, in 1913 and 1914. Profiting by the unexampled opportunities afforded. by the Soviet Government, he began in 1919 to study the natural variation of the ancestral species of cultivated plants. His special method was to use the geographical distribution of particular gene variations in determining the centre of their diversity, which he presumed to be the site of their origin. He applied this method to all the principal crop plants, leading expeditions to all parts of the world. This enabled him to infer the centres of origin of these plants. The most interesting example of this method concerns the wheats. The cultivated forms were already known to fall into two inter-sterile groups, the tetraploids like $T$. durum, $T$. turgidum, $T$. polonicum, and the hexaploids like $T$. vulgare and $T$. compactum. Vavilov found that the hexaploids had arisen from a Central Asiatic centre, while the tetraploids had arisen from an entirely different centre in North Africa, hence the association of the two groups of wheat with different lines of human cultural development.

THE precise value of Prof. Vavilov's methods and the importance of his "Law of Homologous Series in Variation", and his principles of regional selection, are only beginning to be appreciated, but his pub. lished work undoubtedly represents the most important systematic attempt to study natural variation in plants since De Candolle and Darwin. Since 1921, Vavilov has been director of the Institute of Plant Industry. Under his control, this organization has come to embrace stations distributed all over the Soviet Union. Vavilov has used his centralized authority to secure a co-ordination of genetics, cytology, physiology and taxonomy, in which more than two thousand trained workers are engaged in problems of the efficient utilization of plants in the national economy. The work of acclimatization and hybridization carried out by the Institute bears witness to the success of his work, a success which is due to the combination of an enlightened method of inquiry with an industry, enthusiasm and organizing capacity suited to the heavy responsibilities given him by the Soviet Government.

\section{International Geological Congress, 1937}

Is spite of the difficulties which the International Congress of Genetics appears to be meeting, Soviet geologists are busy preparing for the eighteenth International Geological Congress, of which the opening plenary meeting will be held in Moscow on July 21. The session will close on July 29. Excursions, both prior to and following the Congress, are being arranged for delegates and their families. Pre-Congress tours, beginning on July 1, include the following: ( $A$ 1) Karelia and the Kola Peninsula : Pre-Cambrian; igneous complexes; ore deposits ; (A 2) Ukraine and Crimea: Pre-Cambrian; Donets Coal Basin; Crimean stratigraphy and tectonics; (A 3) Volga: stratigraphy of the East European
U.S.S.R. ; Caspian depression; salt domes ; engineering problems; $(A 4)$ Caucasus : stratigraphy; tectonies; igneous activity and ore deposits; $(A 5)$ South Urals, Kazan and Donets Basin : stratigraphy and palæontology of the western slope of the Urals. The longer August excursions, the first two of which will occupy forty days, are as follows: ( $C$ 1) Urals, Caspian, Caucasus : the principal oil deposits of the U.S.S.R. ; $(C 2)$ Siberia : Caledonian, Variscan and Alpine tectonics; Palæozoic and Mesozoic stratigraphy and associated coal and iron deposits; $(C$ 3) Novaya Zemblya : stratigraphy and tectonics; Caledonian granites and mineralization; $(C 4)$ Urals : gabbro-peridotite and alkali complexes; mineral deposits of great variety. Full details and conditions of membership are given in the Third Circular, issued by the Organization Committee, copies of which may be obtained from the General Secretary, Moscow 17, Bolshaya Ordynka, 32. All arrangements for travelling, hotel accommodation, etc., are in the hands of Intourist, Ltd., Bush House, Aldwych, London, W.C.2.

\section{Races in the British Isles}

IT is generally considered more or less a fixed point in discussion of the racial history of the British Isles that a fundamental element in the population, which appears at least as early as the long barrow, is of Mediterranean origin. It will, therefore, come as a surprise to many to find that arguments subversive of this view have been put forward recently by Dr. G. B. Morant ( $J$. Roy. Anthrop. Inst., 66, Pt. 1) in an analysis of the material upon which Dr. Cecil P. Martin based his study of the racial composition of the Irish people in "Prehistoric Man in Ireland" (London: Macmillan and Co., Ltd., 1935). Dr. Martin's conclusions pointed to a virtual identity of racial history in Ireland and Britain up to the intrusion of the Romans and Saxons in Britain. Ireland, however, on the whole was said to have a larger Iberian element and a smaller Nordic element than Britain. Dr. Morant, after a statistical analysis of the modern Irish material, has arrived at the conclusion that the modern Irish and the British Iron Age population are so similar that they might be samples from the same material, while the latter bear the same relation to the population of the Whitechapel plague pit of the seventeenth century. The Anglo-Saxon is slightly removed; but the modern English and the modern Irish might well be considered variants of one race.

ON this argument, it would, therefore, appear that the Iron Age population absorbed the Anglo-Saxon type. Further, this race, with which Dr. Morant would class the British Neolithic, on comparison with Continental types, emerges as essentially Nordic It is comparable with the prehistoric Scandinavian, the Reihengraber people, the Merovingians of northern France, and the Belgian Franks-all Nordics. Dr. Morant justifies the inclusion of the British Neolithic in this group on the evidence of stature and head-measurement, pointing out that 
the extreme length characteristic of the Nordic skull, in which it exceeds any of the dolichocephalic Mediterranean skulls, is also a character of the British neolithic skull. He argues, therefore, that there is no evidence in skeletal remains for the early presence of a Mediterranean element in Neolithic Britain, but that this has been inferred on cultural evidence only. It will be noted that the important character of pigmentation does not enter into the argument; but as has been pointed out on more than one occasion, the argument from pigmentation in the classification of the prehistoric races of Europe rests solely on inference from modern distributions, until in the historic succession we come to the evidence reported in the classical writers.

\section{Golonial Medical Reports}

Major P. GRanville EdGe read a paper before the Royal Statistical Society on January 19 entitled "The Demography of British Colonial Possessions", in which some of the outstanding details to be found in Colonial medical reports were summarized. It was pointed out that the British Colonies comprise upwards of fifty distinct Governments, with territories exceeding an area of two million square miles, of which more than nine-tenths lies wholly within the tropics, inhabited by a bewildering medley of races, religions, languages and customs. The bulk of the people of British tropical Africa are native-born Africans, but in British Malaya the Chinese outnumber the indigenous Malays, and in the British West Indies no traces of the original Carib inhabitants survive, the present population being composed of descendants of African slaves, East Indians, Europeans and other inter-racial mixtures. The Colonial medical reports contain records of population, births, and deaths, so far as these are known, and in addition survey the records of sickness in the Colonies with the view of discovering and removing the predisposing causes of various diseases. The incidence in different parts of the world of such diseases as malaria, helminthiasis, venereal affections, dysentery, sleeping sickness and tuberculosis were discussed by Major Granville, and the difficulties connected therewith commented upon. The public health services, wherever located, may be regarded. as fighting organizations engaged in combating insanitary conditions, in raising defences against the invasions of disease, and in attempting to stave off the approaches of death. Without these services detailed sanitary knowledge cannot be acquired, and without such knowledge commercial and other development of the Colonial Empire must be precarious and costly in the face of unrealized menaces to life and health.

\section{Magnesium Alloys for Aircraft}

As the standards of aireraft performance are raised, possible saving of weight is becoming of ever greater importance, so that more and more interest is being taken by aircraft construetors in metals lighter than aluminium. On January 14, Dr. C. H. Desch, superintendent of the Metallurgical Department of the National Physical Laboratory, discussed, before the Royal Aeronautical Society, recent work on magnesium and other light alloys, much of which has been carried out at the National Physical Laboratory. Magnesium is too weak a metal to be used in the unalloyed state, and the metals which may be added to it to produce strong alloys are limited in number. In fact, taking all the factors into account, only aluminium and cadmium are suitable for alloying in comparatively large quantities, although calcium, cerium, nickel, cobalt and manganese have proved useful in small quantities. To those who have only known magnesium in the form of ribbon or powder for use in flashlights, it is rather surprising to find that magnesium alloys are remarkably easy to cast. This comes about, Dr. Desch said, from the fact that molten magnesium has very little power of dissolving gases, so that magnesium alloys do not suffer from porosity caused by the liberation of gases at the moment of freezing. It is necessary to use a suitable flux and a protective atmosphere during pouring. These conditions are now well understood, and no difficulties are experienced in the foundry. In annealing processes similar protection is necessary, and the special technique adopted has resulted in making a magnesium alloy foundry a remarkably clean and inoffensive place. Exhaustive search at the National Physical Laboratory for magnesium alloys capable of age-hardening has suggested that those containing silver are the most promising. The fact that silver is relatively costly is of little importance, since in the articles of the type produced the cost of manufacture is much greater than that of the material used.

\section{Afforestation in the Lake District}

AN interesting pamphlet has been issued by the Forestry Commissioners entitled "Afforestation in the Lake District" (London : H.M. Stationery Office, 1936). The pamphlet embodies the report by the Joint Informal Committee of the Forestry Commission and the Council for the Preservation of Rural England which was set up early in 1935. The Committee commenced its task with the recognition that large-scale afforestation and the preservation of areas of typical natural beauty are both necessary on national grounds, and that the land available for both purposes is limited. This does not entirely represent the actual position of affairs. For the public in some cases in the past have not only been against new afforestation work, but also have declaimed at old woods, such as are to be found in some of the enclosures in the New Forest, for example, being touched; in spite of the fact that it is evident that the old trees cannot last for ever. Towards the end of 1935 , the Commissioners acquired an estate of 7,000 acres in the valley of the River Esk and the adjacent valley of Duddon, and prepared to plant. Objections were made by the public to the planting of conifers in the two valleys, especially in Upper Eskdale. It was agreed that some 440 acres of plantation land in Upper Eskdale should be omitted from the planting scheme, the Commissioners 